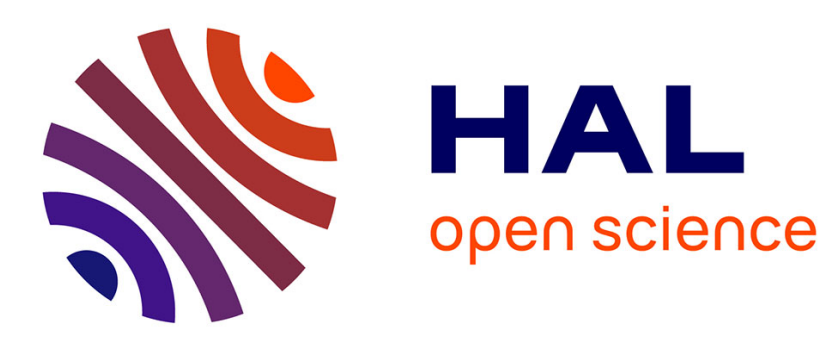

\title{
Early to late Holocene vegetation and fire dynamics at the treeline in the Maritime Alps
}

Walter Finsinger, Quentin Vanel, Adriano Ribolini, Willy Tinner

\section{To cite this version:}

Walter Finsinger, Quentin Vanel, Adriano Ribolini, Willy Tinner. Early to late Holocene vegetation and fire dynamics at the treeline in the Maritime Alps. Vegetation History and Archaeobotany, 2021, 30, pp.507-524. 10.1007/s00334-020-00795-x . hal-02937486

\section{HAL Id: hal-02937486 \\ https://hal.science/hal-02937486}

Submitted on 1 Nov 2020

HAL is a multi-disciplinary open access archive for the deposit and dissemination of scientific research documents, whether they are published or not. The documents may come from teaching and research institutions in France or abroad, or from public or private research centers.
L'archive ouverte pluridisciplinaire HAL, est destinée au dépôt et à la diffusion de documents scientifiques de niveau recherche, publiés ou non, émanant des établissements d'enseignement et de recherche français ou étrangers, des laboratoires publics ou privés. 
2 The authors do not recommend the distribution of this version of this article.

3

4

5

6

7

8

The article is freely available upon request.

To receive a copy, please send a request to Walter Finsinger at: walter.finsinger@umontpellier.fr

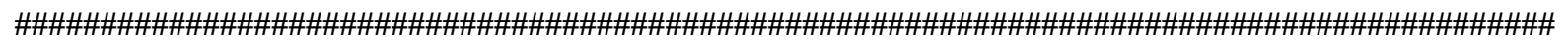

\section{Early-to-late-Holocene vegetation and fire dynamics at the treeline in the} Maritime Alps

\section{Published in Vegetation History and Archaeobotany (2020)}

\author{
Walter Finsinger ${ }^{*}$, Quentin Vanel ${ }^{2}$, Adriano Ribolini ${ }^{3}$, Willy Tinner ${ }^{4}$ \\ 1 - ISEM, University of Montpellier, CNRS, EPHE, IRD, Montpellier, France \\ 2 - Ecosphère, Agence Nord-Ouest, 28 rue du Moulin, 60490 Cuvilly, France \\ 3 - Dipartimento di Scienze della Terra, Universitá di Pisa, Pisa, Italy \\ 4 -Oeschger Centre for Climate Change Research and Institute of Plant Sciences, University of Bern, \\ Altenbergrain 21, CH-3013 Bern, Switzerland
}

20 


\section{Abstract}

22 We used pollen, plant-macrofossil, and charcoal records to unfold local long-term timberline shifts and changes 23 in vegetation composition in relation to fire activity at the modern upper forest limit (ca. $2000 \mathrm{~m}$ asl) in the Mont

24 Bégo area. The area is an iconic place for Alpine archaeology because it bears thousands rock-art engravings 25 whose age cannot be directly assessed. Our new record confirms the occurrence of distinct land-use phases 26 (7450-7150, 6200-4900, and 4250-3700 cal BP), as suggested by prior studies based on rock-art typology. 27 Moreover, the macrofossil-inferred vegetation reconstruction (co-dominance of Pinus and Betula) suggests that early-Holocene conditions were moister than in dry inner-alpine valleys, where Larix decidua played a more 29 important role, both in past as well as in modern timberline forests. After $8000 \mathrm{cal} \mathrm{BP}$, the timberline shifted to 30 higher elevation and mixed Abies alba and Pinus cembra stands established around the study site. These fire31 sensitive tree populations were definitely replaced during the Bronze Age (around 4000 cal BP) by L. decidua 32 that still dominates the subalpine forests in the area today. Our study supports the notion that while the range (or 33 realized climatic niche) of $A$. alba has been reduced at the colder-end of its natural distribution that of $L$. decidua 34 has been widened by land-use changes and fire disturbances to create high-alpine pasture woodlands.

36 Keywords: Vegetation dynamics; mountain ecosystems; treeline ecotone; land-use phases; pasture woodlands; fires 
The altitudinal treeline ecotone is a prominent ecosystem boundary in mountain landscapes (Arno and Hammerly 1984) at the transition between the upper limit of closed forests (timberline, i.e. the upper limit of subalpine forests) and open alpine meadows (beyond the upper tree species limit) (Körner 2003). While the species composition of the treeline ecotone and of subalpine forests is mainly influenced by water availability, rainfall, soils, and disturbances (Henne et al. 2011; Schwörer et al. 2014a), the upper limit of tree growth is primarily determined by temperature at the regional scale (Körner and Paulsen 2004; Holtmeier and Broll 2005; Holtmeier 2009). Therefore, climatic changes are expected to lead to both altitudinal shifts in its position and changes in species composition (Walther et al. 2005; Heiri et al. 2006). However, in addition to being influenced by these factors, both the position and composition of the timberline and of subalpine forests can be substantially modified by land use (Arno and Hammerly 1984). In the European Alps, with its long history of land-use (Millennium Ecosystem Assessment 2005), subalpine forests and treeline ecotones have been used and exploited for millennia to create pastures and grazing meadows, often with the use of fire (Tinner 2007).

Palaeoecology provides long-term records of changes in timberline position and composition (Tinner 2007), and into past trends of fire activity (Conedera et al. 2009). Such proxy-based reconstructions are relevant for estimating vegetation responses to changing environmental conditions and land-use changes (Tinner 2007), thereby unfolding cultural legacies on forested landscapes that are often viewed as 'ancient' (Willis and Birks 2006; Feurdean et al. 2009). As a result, a growing number of studies have focussed on long-term treeline dynamics in the European Alps (e.g. Lang and Tobolski 1985; Tinner et al. 1996; Wick and Tinner 1997; Wick et al. 2003; Tinner and Kaltenrieder 2005; Lotter et al. 2006; Finsinger and Tinner 2007; Blarquez et al. 2010; Berthel et al. 2011; Rey et al. 2013; Schwörer et al. 2014b) and elsewhere (e.g. Herring et al. 2018; Orbán et al. 2018; Finsinger et al. 2018). In this study, we focus on treeline vegetation and fire dynamics from the Vallée des Merveilles and Mont Bégo (2872 $\mathrm{m}$ asl) area, an iconic area in the Argentera Massif better known for the 36,000 rock arts distributed among c. 4200 rocks between 2000 and $2700 \mathrm{~m}$ asl that were already described in the $16^{\text {th }}$ century (Arcà 2018) and more intensely studied since the end of the $19^{\text {th }}$ century (Bicknell 1913; Conti 1940, 1972; de Lumley 1984, 1995). Recently, a chronological framework of land-occupation and land-abandonment phases has been proposed (Binder et al. 2009; Huet 2017). .However, because rock engravings could not be dated directly (they lack calcite crusts or organic material), their ages were estimated based on rock-art typology, data from archaeological excavations and 
67 pollen records (increases of herb pollen such as Artemisia, Chenopodiaceae and Poaceae) (de Beaulieu 1977; 68 Kharbouch 2000). Moreover, with the exception of pollen from crops and adventive weeds, increases of herb pollen 69 in high-elevation lake sediments may also be indicative of climate-induced treeline shifts to lower elevations (Heiri et al. 2006). In addition, fires can have a significant and long-lasting impact on vegetation structure and composition by promoting open spaces and fire-resistant species, and disfavouring fire-sensitive species (Stähli et al. 2006; Leys et al. 2014; Schwörer et al. 2015). New taxonomically highly resolved palaeoecological records that include both plant macrofossils and charcoal records may substantially improve knowledge on local vegetation and fire dynamics at the treeline ecotone in the study area, thereby providing a better link between long-term vegetation dynamics, changing environmental conditions, and findings of archaeological artefacts, rock engravings, and land-use phases. Both charcoal and plantmacrofossil records may be relevant proxies in this study area, for at least three reasons. Firstly, in mountain settings the combination of plant-macrofossil and charcoal records can allow apprehending past vegetation dynamics and vegetation responses to changing environmental conditions and fire disturbances better than with wind-dispersed pollen (Birks and Birks 2000). Secondly, pollen records (de Beaulieu 1977; Kharbouch 2000; Finsinger 2001; Ortu et al. 2003) suggest that fire-sensitive Abies alba populations (Tinner et al. 1999) were more abundant during the mid Holocene in the region. However, it is unclear at which elevation populations of this temperate tree species were able to dominate, and how these populations responded to changing environmental conditions and disturbances (including fires). Thirdly, the modern timberline is dominated by Larix decidua (Ozenda 1950; Barbero et al. 1973), which is heavily under-represented in pollen records (Sjögren et al. 2008) but much better represented in plantmacrofossil records because it sheds its needles in high numbers every year (Tinner and Theurillat 2003). We selected as study site the Lac des Grenouilles (1994 m asl), which is located at about the modern timberline (c. $2000 \mathrm{~m}$ asl; Ozenda 1950) and below the modern potential treeline in the Mont Bégo rock-art area (Fig. 1a).

89 Littoral sediments from this lake already have been analysed for pollen (Kharbouch 2000). However, that sediment sequence was fragmentary (with hiatuses), and no plant-macrofossil and charcoal analyses were

91 conducted. Here we present novel temporally and taxonomically highly resolved pollen, spore, stomata, plantmacrofossil, and charcoal records from sediments collected from the lake centre. Due to its small size $(0.015$ $\mathrm{km}^{2}$ ), the lake should collect sufficient plant macrofossils, thereby allowing the reconstruction of past vegetation dynamics in the close surroundings. Because we were particularly interested in characterizing local-scale changes in fire activity and vegetation dynamics prior to and during prehistoric land-use phases (7350-3700 cal 
BP), we performed high-resolution macroscopic charcoal and plant-macrofossil analyses for early-to-late

Holocene sediments (Mesolithic - Early Bronze Age) sediments (10,000-3400 cal BP). In addition, we conducted high-resolution palynological analyses for Neolithic to Early-Bronze Age sediments to investigate fire-vegetation relationships using time-series analyses (Green 1981; Schwörer et al. 2014b).

100

\section{Materials and Methods}

Study area

104 Lac des Grenouilles $\left(44^{\circ} 05^{\prime} 53^{\prime \prime} \mathrm{N}, 7^{\circ} 29^{\prime} 07^{\prime \prime} \mathrm{E} ; 1994 \mathrm{~m}\right.$ asl) is situated on the south-facing slope of the Argentera Massif (Maritime Alps, southwestern Alps; Figure 1a) at the lower end of a hanging valley. Two small seasonal streams feed the lake, and one outflow drains into the Vallon de Fontanalba, a tributary of the Vallon de Casterino (Roya River basin). At the southeastern end of the Vallon is Mont Bégo, which separates that valley

108 from the Vallée des Merveilles. The majority of rock engravings is centred in the Vallée des Merveilles as well as in the upper part of the Vallon de Fontalba (Figure 1a; Huet, 2017). Bedrock in the Mont Bégo area is dominated

110 by Permian granitoid and metamorphic rocks (Malaroda et al. 1970). However, Triassic-Jurassic calcareous and 111 dolomitic rocks and Grauwackes occur on the northern slope of the hanging valley (Faure-Muret 1967).

112 The study area lies at the edge of the inner-alpine zone (Figure 1b), which is characterised by higher 113 continentality (higher temperature seasonality and less rainfall) than the outer and intermediate

114 (“Zwischenalpen”) zones (Ozenda 2002; Landolt 2003). Sub-alpine forests in the inner-alpine zone are dominated by Pinus cembra, L. decidua, and Pinus sylvestris (Ozenda 1985, 2002; Landolt 2003). In the Mont

116 Bégo area, the treeline ecotone and the subalpine forests are dominated by open L. decidua pasture woodlands 117 with minor shares of P. cembra, P. uncinata, and P. sylvestris, and Juniperus communis and Ericaceae shrubs

118 (Rhododendron hirsutum, and Vaccinium myrthillus) characterize the forest understorey. While the timberline is 119 located at c. $2000 \mathrm{~m}$ asl, isolated L. decidua and P. cembra tree stands can be found up to c. 2300 and individual 120 trees (> c. 2m) up to $2400 \mathrm{~m}$ asl (Ozenda 1950; de Beaulieu 1977, own observations). On the northern, more

121 humid, slope of the Massif, the timberline is generally substantially lower (c. $1700 \mathrm{~m}$ asl) and Fagus sylvatica is 122 more abundant than on the southern slopes (Ozenda 1950). In the area trees can be found up to c. $2300-2400 \mathrm{~m}$ 123 asl (Barbero et al. 1973). A. alba-dominated forest stands occur few kilometres to the south of the study site 124 (Ponel et al. 2001) at altitudes of c. 900 to $1600 \mathrm{~m}$ asl (Barbero and Bono 1970), i.e. c. $400 \mathrm{~m}$ below the study 
125 site at current timberline and c. $800 \mathrm{~m}$ below treeline. At Lac des Grenouilles, mean monthly temperatures are

126 around $-2^{\circ} \mathrm{C}$ in winter, and $13^{\circ} \mathrm{C}$ in summer. The mean annual precipitation is about $1000 \mathrm{~mm}$. Monthly rainfall

127 shows the influence of the Mediterranean climate with a bimodal distribution (maxima in spring and autumn

128 with c. 100-115 mm month ${ }^{-1}$ ) and a comparatively drier summer (c. $50 \mathrm{~mm} \mathrm{month}^{-1}$ ) (Fick and Hijmans 2017).

$130 \quad$ Fieldwork and sediment-core correlation

131 A geomorphological survey was undertaken in the area around Lac des Grenouilles. The survey was particularly 132 focussed on glacial and periglacial landforms (Figure 1c). Two overlapping sediment cores (Gren-2 and Gren-3)

133 were collected in the year 2001 in 1-m long drives from a floating platform in the lake's centre with a modified

134 Livingstone piston cover (Merkt and Streif 1970) at $286 \mathrm{~cm}$ water depth. Core Gren-2 was collected with a 135 smaller-diameter barrel $(5 \mathrm{~cm})$ than core Gren-3 $(8 \mathrm{~cm})$. Sediment-core drives were longitudinally cut into halves 136 using an electro-osmotic guillotine (Sturm and Matter 1972), and photographed with a digital camera and 137 artificial-light equipment at the Institute of Plant Sciences (University of Bern). We subsequently used the 138 changes in lithology to correlate the sediment cores (Figure 2) and establish core depths for the $615 \mathrm{~cm}$ long 139 master core.

\section{Chronology}

142 The depth-age model is constrained by the following control points: the estimated age of the surface sediments 143 (c. the year of coring), 13 AMS radiocarbon $\left({ }^{14} \mathrm{C}\right)$ dates extracted from core Gren-3 from terrestrial plant remains 144 (Finsinger et al. 2019), and a pollen-inferred age set to constrain the Younger Dryas/Holocene boundary 145 (following Giesecke et al. 2014) (Table 1). The two lowermost ${ }^{14} \mathrm{C}$ dates were rejected because they provided 146 unrealistically young ages in comparison to all other age determinations, including regional biostratigraphy.

147 Radiocarbon ages were calibrated to calendar ages using the IntCal13 data set (Reimer et al. 2013) prior to fitting 148 a smoothing spline (Figure 2) using the CLAM v2.2 software (Blaauw 2010). Distinct turbidite layers, most 149 likely representing sediment deposition that occurred over a very short time span (hours, days), were excluded 150 from the depth-age model (Figure 2), following Heiri et al. (2003). Therefore, except where otherwise mentioned 151 all references to sediment depth hereafter refer to a corrected sediment depth that excludes turbidites. 
154 Sediment samples (volume: $1 \mathrm{~cm}^{3}$; thickness: $1 \mathrm{~cm}$ ) for pollen analysis were treated with standard physical and 155 chemical treatments (incl. $\mathrm{HCl}, \mathrm{KOH}$, sieving with a 500- $\mu \mathrm{m}$ mesh and decanting, $\mathrm{HF}$, and Acetolsyis), coloured 156 with Fuchsin, and mounted in glycerine jelly. Pollen and spores were identified and counted using pollen keys 157 (Punt et al. 1976; Reille 1992; Moore et al. 1998) and the reference collection at the Institute of Plant Sciences 158 (University of Bern). Stomata were identified based on Trautmann (1953) and Finsinger and Tinner (2020) and 159 dung-fungi Sporormiella spores were identified based on Davis (1987). Results are presented as percentages of 160 the terrestrial pollen sum, which includes pollen from trees, shrubs, and herbs (spores and pollen of aquatic 161 plants were excluded; Figures 3a and 4). Sampling resolution was increased to one sample each 1-4 $\mathrm{cm}$ in the 162 portions between $298-387 \mathrm{~cm}$ and $392-450 \mathrm{~cm}$ depth. Pollen can be dispersed by wind over large distances and generally integrates vegetation at extra-local to landscape scales (Sugita 1994). While the small area of the site

$164\left(0.015 \mathrm{~km}^{2}\right)$ might suggest that the pollen source area could be substantially smaller (e.g. several hundred meters to a few kilometres at most; Sugita 1994; Conedera et al. 2006), landscape-scale pollen from lower-elevation 166 areas may reach the site, which is located in an area with steep topography (Finsinger et al. 2007). By contrast, stomata and Sporormiella spores should be considered local-scale indicators of the presence of the parent trees

168 (Ammann et al. 2014) and large herbivore density (Baker et al. 2013; Gill et al. 2013), respectively.

169 For plant macrofossils, sampling was mostly continuous between 284 and $460 \mathrm{~cm}$ depth. We measured sample 170 volume by water displacement (volumes vary between $12 \mathrm{~cm}^{3}$ and $19.25 \mathrm{~cm}^{3}$; median: $16 \mathrm{~cm}^{3}$ ). Samples were 171 soaked in a $10 \% \mathrm{NaP}_{2} \mathrm{O}_{4}$ solution for 24 hours and sieved with water through a $250-\mu \mathrm{m}$ mesh. Identification of 172 plant macrofossils was performed under a dissecting microscope (7.5X) and achieved by comparisons with 173 reference collections stored at the Institute of Plant Sciences (University of Bern), at the University of 174 Montpellier, and atlases (Cappers et al., 2006; Schoch et al., 1988; Tomlinson, 1985). To account for varying 175 sample volumes, the results are presented as concentrations calculated with respect to a standard sediment 176 volume of $10 \mathrm{~cm}^{3}$ (Figure 3b). Plant macrofossils were grouped and summed by genus to compare them with the 177 pollen percentage records (Figures $3 \mathrm{~b}$ and 4). Plant macrofossils are dispersed over substantially shorter 178 distances than pollen, and therefore better reflect local-scale vegetation within some decametres around the site 179 (Birks and Birks 2000; Birks and Bjune 2010).

180 For macroscopic charcoal analysis, contiguous samples (volume: $1 \mathrm{~cm}^{3}$; thickness: $1 \mathrm{~cm}$ ) were taken between 181283 and $460 \mathrm{~cm}$ depth. Samples were first soaked in a $10 \% \mathrm{NaP}_{2} \mathrm{O}_{4}$ solution for 24 hours and then gently washed 182 through a $160-\mu \mathrm{m}$ mesh using a manual water spray. The remaining particles were subsequently bleached in a 
$1832.6 \% \mathrm{NaOCl}$ solution for a few minutes to distinguish charcoal from dark organic matter, following Genries et

184 al. (2012). The number and area of charcoal fragments were estimated under a dissecting microscope (at a 185 magnification of x6.3) connected to a digital camera and using image analysis software (Winseedle pro v.2007).

186 Charcoal concentrations (both as total number and area per sample) were converted to charcoal-accumulation 187 rates (hereafter denoted as CHAR) to account for variations in sedimentation rate (Whitlock and Larsen 2001).

188 Calibration studies suggest that charcoal particles larger than $600 \mu \mathrm{m}$ might be of local origin, while smaller 189 particles can easily be dispersed over large distances (up to 30-50 km; Oris et al. 2014; Adolf et al. 2018). 190 Therefore, the low-frequency trends of the macroscopic charcoal record can be attributed to overall landscape191 scale fire activity (Marlon et al. 2008; Adolf et al. 2018). We estimated the low-frequency trend by fitting loess 192 smoothing (Cleveland and Devlin 1988) to the macrocharcoal influx values (Figure 4).

193 Pollen-assemblage zones were determined by optimal partitioning with square-root transformed percentage 194 values for pollen types included in the pollen sum (Birks and Gordon 1985). Statistically significant zones 195 (continuous lines in Figure 3) were assessed by comparison with the broken-stick model, following Bennett 196 (1996). Zonation was performed with Psimpoll v4.26 (Bennett 2008). The programs Tilia v2.6.1 and Affinity 197 Designer v1.7.0 were used to plot the pollen and plant-macrofossil diagrams (Figure 3).

Time-series analyses

200 To investigate leads and lags between fire activity (charcoal influx) and vegetation (pollen percentages), we use cross-correlation analyses (Green 1981; Tinner et al. 1999; Rey et al. 2019). Analyses were restricted to the higher-resolution section between 387 and $298 \mathrm{~cm}$ depth (6950-3750 cal yr BP) where the median sampling resolution is of 48.5 years between samples (n. of samples: 49) and the median absolute deviation is 26.7 years (Figure S1). This analysis requires homogeneously spaced time series sampled at the same time resolution 205 (Venables and Ripley 2002). Thus, we fitted a loess-smoothed line (span=0.15) to estimate pollen percentage and charcoal influx values at 100-year intervals (Figure 4). Cross-correlation analyses were performed under the

207 R computing environment ( $R$ Core Team 2017). Cross-correlation coefficients are presented for maximum lags of \pm 4 corresponding to \pm 400 years (Figure 5). As in our time series the loess-smoothed values are not entirely independent, the $95 \%$ confidence intervals must be viewed with caution (Venables and Ripley 2002, p. 390). 


\section{Results and interpretation}

213

\section{Geomorphological context}

215 Lac des Grenouilles is dammed by a prominent lateral moraine mantling the left flank of the Vallon de 216 Fontanalba (Figure 1c). According to regional reconstructions (Cossart 2008; Federici et al. 2012, 2017; Cossart

217 et al. 2012), the moraine formed during the Last Glacial Maximum (LGM) and the moraines mapped further 218 upvalley (around 2200-2300 m asl) were probably deposited during the Younger Dryas cold event (Egesen 219 stadial), as observed on the northern side of the Maritime Alps (Spagnolo and Ribolini 2019). The sparse glacial 220 debris in the area of Lac Ste Marie suggests the presence of relict ice bodies or glacierets also during the 221 Holocene cold events. Part of this debris, which is locally mixed with rock falls, experienced the formation of 222 permafrost. Permafrost creeping led to the formation of a rock glacier located around $2400 \mathrm{~m}$ asl. According to 223 permafrost-monitoring data in the Maritime Alps (Ribolini and Fabre 2006; Ribolini et al. 2007, 2010), 224 permafrost in the rock glacier could be still present.

227 Three statistically significant pollen-assemblage zone boundaries were determined (Figure 3a). The zone at the 228 bottom (Gren-1; >467 cm; >10,700 cal BP) probably corresponds to the late-Glacial and early-Holocene because pollen assemblages reflect a well-established pattern of late-Glacial pollen stratigraphies from the study area (de

230 Beaulieu 1977; de Beaulieu et al. 1994; Finsinger and Ribolini 2001). This chronological attribution is consistent with the geomorphological context, with an LGM moraine that dammed Lac des Grenouilles. Pinus, Artemisia,

232 and Poaceae dominate pollen assemblages below $490 \mathrm{~cm}$ depth, with minor abundances of Betula, deciduous 233 Quercus, and Juniperus pollen. Around 12,000 cal BP, abundances of Artemisia and Ephedra pollen are higher 234 than in prior samples, and Pinus pollen abundance is lower, suggesting an opening of the vegetation that may 235 reflect the effects of the Younger Dryas cooling (12,850-11,650 cal yr BP; Rasmussen et al. 2014) in the Alpine 236 region (Larocque and Finsinger 2008; Samartin et al. 2012). Plant macrofossils (Figures 3b and 4) indicate that 237 Larix was present in the surroundings shortly prior to the onset of the Younger Dryas, and that Dryas octopetala 238 carpets briefly expanded at the Younger Dryas/Holocene transition. Sporormiella dung-fungi spores were regularly found, suggesting the presence of large herbivores near the lake during the late Glacial. A shift to closer

240 vegetation with higher abundance of Betula, increasing arboreal pollen, a decrease of Artemisia and herb pollen, 
241 and the first appearance of Tilia pollen characterizes the transition to the warmer Holocene.

242 The transition to zone Gren-2 (467-397 cm; 10,700-7450 cal BP) is marked by the rise of Quercus pollen 243 abundance, and the first appearance of Corylus, Fraxinus, Alnus glutinosa, and Acer pollen indicating that 244 thermophilous tree populations expanded, probably at lower elevation. The continuous presence of Betula 245 macrofossils and the rare occurrences of Pinus mugo and Juniperus needles suggest that the site was at the 246 treeline ecotone and that open Betula-Pinus stands were located in the surroundings. Rare occurrences of Alnus 247 viridis pollen and the absence of its macrofossils suggest that populations were either very sparse or distant. In 248 spite of decreasing Pinus pollen abundance, arboreal pollen abundance is highest (ca. 75-90\%) in this zone. As 249 observed in other records (Tinner and Hu 2003; Finsinger et al. 2014), the two charcoal-influx records (by counts 250 and by area) are highly redundant $(r=0.912, p$-value $<0.001$; Figure $\mathrm{S} 2)$. Thus, only the charcoal-influx record by 251 count is used in the following discussion. Fire activity was overall low (CHAR values $<0.1$ pieces cm $\mathrm{cear}^{-1}$; 252 Figure 4).

253 Increasing abundance of Abies pollen and abundant finds of its plant-macrofossils in zone Gren-3 (397-330.5 $254 \mathrm{~cm} ; 7450-4700 \mathrm{cal} \mathrm{BP}$ ) indicate the rise of the timberline and the establishment and expansion of a subalpine 255 forest in the surroundings. While light-demanding Betula populations shrank as shown by decreasing pollen and 256 macrofossil abundance, increasing pollen abundance and needle finds indicate that $P$. cembra populations 257 expanded. Pollen and plant macrofossil abundances of light-demanding Larix were low until c. 6000 cal BP, 258 when Larix populations started to expand. Increasing herb pollen abundance and charcoal influx values (CHAR 259 values $>0.1$ pieces $\mathrm{cm}^{-1}$ year-1) suggest that forest cover decreased due to rising fire activity. Fire-sensitive Abies 260 populations, however, collapsed some 500 years later when a further rise in fire activity occurred. 261 Simultaneously, Larix populations further expanded and Betula pollen increased, indicating a major shift in the 262 composition of the subalpine forest cover. Between 4800 and 4300 cal BP (around transition into zone Gren-4: $263330.5-220 \mathrm{~cm} ; 4700-2000 \mathrm{cal}$ BP) high arboreal pollen percentages suggest the partial recovery of forest cover 264 during a c. 500-years long period of low fire activity. Regular findings of plant macrofossils indicate that mixed 265 Abies populations re-expanded in the subalpine forest around the site. Around 4300 cal BP, fire activity increased 266 again and the composition of the subalpine forest shifted to a Larix-dominated forest. Decreasing Betula pollen 267 abundance and absence of plant macrofossils suggest that Betula stands, perhaps above the timberline, were 268 strongly reduced. Abies alba and Pinus cembra plant macrofossil abundances strongly decrease after $4300 \mathrm{cal}$ 269 BP, pointing to local extinctions of the two species. 
270 Variations in the relative abundance of cultural indicator pollen from crops and weeds as well as Sporormiella

271 dung-fungi spores document transient phases of human pressure. We found moderately higher values of

272 Artemisia and Urtica pollen, and of Sporormiella spores around 7450-7150 cal BP. Sporormiella spores'

273 abundance shows a local maximum around 6200-5500 cal BP, together with an increase of Poaceae and Rumex

274 pollen and the regular occurrence of Cerealia-type and Plantago lanceolata-type pollen. Similarly, Poaceae,

275 Rumex, Veratrum, Trifolium pratense-type, and P. lanceolata-type pollen, and Sporormiella spores abundance

276 increase after $4300 \mathrm{cal}$ BP. In all of these three phases, arboreal pollen percentages are substantially reduced,

277 indicating transient openings of the subalpine forests in response to prehistoric land-use activities.

278

279 Time series analyses

280 Pollen percentages of herb pollen have significant positive correlations with charcoal influx (maximum 281 correlation at lag 0; Figure 5). The Poaceae illustrate particularly well the expansion of grasslands as a 282 consequence of forest-cover reduction in response to increasing fire activity, as also observed in other studies 283 (Rey et al. 2013, 2019). However, positive correlations of cultural indicators (P. lanceolata and Urtica) are 284 delayed, suggesting a gradual intensification of land use after fires, as also observed in another record from the 285 Alps (Gobet et al. 2003). By contrast, Sporormiella shows positive correlations at negative lags, suggesting that 286 grazing by large herbivores preceded increases in fire activity.

287 Most tree taxa (Abies, Betula, and Pinus) show negative correlations with charcoal influx. Abies is negatively 288 correlated at positive lags, suggesting either a slightly higher fire tolerance or less intense disturbance, if compared to warmer lowland sites (Tinner et al. 2000), a finding that is in agreement with other high-resolution 290 mountain studies (Rey et al. 2013; Schwörer et al. 2015). Similarly, Pinus is negatively correlated at positive 291 lags. While this matches with the long-term fire ecology of P. cembra, a tree sensitive to prolonged fire 292 disturbance (Gobet et al. 2003; Schwörer et al. 2015), the clear interpretation of this result is complex because 293 the plant-macrofossil record shows the local presence of Pinus mugo (Gobet et al. 2003; Stähli et al. 2006; 294 Finsinger et al. 2018). Moreover, the contribution of pollen from other Pinus species growing at lower elevation 295 is difficult to estimate. Betula and shrubs are also negatively correlated, but at negative lags. By contrast, Larix is 296 positively correlated at positive lags, suggesting the gradual and delayed expansion of larch-dominated open 297 woodlands. While this contrasts with results from the Engadin, which showed non-lagged negative correlations 298 (Gobet et al. 2003), our results are consistent with evidence of Larix' fast post-fire regeneration (Schöneberger 
and Wasem 1997; Malowerschnig and Sass 2014).

\section{Discussion}

\section{Influence of climate on early-Holocene afforestation}

304 The late Glacial (c. 14,600-11,650 cal BP) vegetation was dominated by grasslands with Artemisia and Poaceae 305 (de Beaulieu 1977; this study), and Pinus probably occurred at lower elevation (de Beaulieu 1977). The absence of Betula plant macrofossils suggests that these trees were either very sparse (de Beaulieu 1977) or locally absent. The findings of $L$. decidua needles and pollen indicate the presence of this conifer tree in the surroundings prior to the Younger Dryas. This corroborates the very rare findings of Larix pollen grains in late

309 Glacial sediments at Selle di Carnino (de Beaulieu 1977), a peaty depression at $1900 \mathrm{~m}$ asl few kilometres to the east from Lac des Grenouilles. These two sites are among the highest-elevation Alpine sites where tree pollen, stomata, and macrofossils suggest tree growth during the Bølling/Allerød (c. 14,600-12,800 cal BP) (Wagner et al. 2015). For instance, the stomata findings of Juniperus, Larix, and Pinus at Simplon-Alter Spittel (1885 m asl)

313 a south-facing site in the Divedro Valley (southern Swiss Alps) showed the early establishment of trees during 314 the Allerød (13,900-12,800 cal. BP) (Welten 1982; Ammann et al. 2014). The substantial drop in summer 315 temperatures during the Younger Dryas cooling in the Alpine region (Heiri et al. 2014) likely led to a treeline depression below Lac des Grenouilles, as no tree macrofossils were found. In other records form the Alpine 317 region treeline depressions of ca. 300-400 m were recorded (Tinner and Vescovi 2005; Gobet et al. 2005). Given 318 that sedimentation was not interrupted at Lac des Grenouilles, the Younger Dryas glacier advance did not reach 319 the site. This is in agreement with geomorphological evidences that suggest the location of Younger Dryas moraines mostly above $2100 \mathrm{~m}$ asl (Brisset et al. 2015; Spagnolo and Ribolini 2019).

321 The plant-macrofossil record supports prior interpretations (de Beaulieu 1977; Ponel et al. 2001) suggesting that treeline was close to $2000 \mathrm{~m}$ asl during the early Holocene in the study area. Specifically, an open Betula and Pinus (probably P. mugo) dominated treeline with scattered Juniperus shrubs re-expanded around Lac des Grenouilles in the early Holocene until c. 8000 cal BP, when the first Abies macrofossil was found. However, 325 due to the lack of ${ }^{14} \mathrm{C}$ dates around the Younger Dryas/Holocene transition (Fig. 2), it is difficult to establish precisely the afforestation lag in response to the early-Holocene warming for Lac des Grenouilles. Pollenindependent temperature reconstructions show rapid warming of c. $2-4^{\circ} \mathrm{C}$ within a few decades after the Younger 

Heiri et al. 2015) that likely led to a rapid early-Holocene treeline rise in the Central and Southern Alps, showing

330 the ability of treelines in tracking climate warming with decadal to centennial lags (Tinner and Kaltenrieder 331 2005). Conversely, other sites suggest that due to the regional setting (e.g. colder Northern Alps) or local 332 peculiarities (soils, aspect, moisture availability), today's treeline positions were only reached at ca. 10,000 cal 333 BP (Schwörer et al. 2014a) or even after 8200 cal BP (Finsinger and Tinner 2007). Nevertheless, we found a 334 short-term early-Holocene expansion of Dryas octopetala, a pioneer species of open, base-rich habitats 335 (Elkington 1971), prior to the expansion of Betula at 11,300 cal BP. This indirectly supports the chronology for 336 Lac des Grenouilles, because early-Holocene expansions of D. octopetala were also detected at Gouillé Rion and 337 at Lac de Fully, two sites above current timberline in the dry inner-alpine Valais (Kaltenrieder et al. 2005b; 338 Finsinger and Tinner 2007) as well as at Iffigsee and Lago Basso (Wick and Tinner 1997; Schwörer et al. 339 2014b).

340 Early-Holocene fire activity was substantially lower than during the mid-to-late-Holocene (Figure 4). We assume 341 that fire activity was limited by low biomass availability, as also observed elsewhere (Berthel et al. 2011; Gil342 Romera et al. 2014; Finsinger et al. 2018). Indeed, high early-Holocene insolation seasonality (Figure 4) likely 343 was a determining factor for climate-induced low biomass availability in high-elevation Alpine landscapes 344 (Schwörer et al. 2014a).

345 The absence of Larix during the early and mid Holocene at Lac des Grenouilles is striking when compared to 346 records from dry inner-alpine valleys. For instance, at Gouillé Rion Salix and D. octopetala tundra preceded the 347 expansion of a Larix-dominated subalpine forest around 11,000 cal BP (Tinner and Kaltenrieder 2005). 348 Similarly, an early-Holocene expansion of Larix has also been recorded at Lac de Fully, another site in the dry 349 inner-alpine Valais (Finsinger and Tinner 2007), at Iffigsee in the northern Swiss Alps (Schwörer et al. 2014b), at 350 Lej da San Murezzan in the Engadine and several other sites of the Swiss Alps (Gobet et al. 2005) as well as at 351 Lac du Loup in the inner-alpine sector of the French Alps (Blarquez et al. 2010) (Figure 1b). Indeed, light352 demanding Larix decidua grows at present mostly in continental climates, with cold, dry, and snowy winters (Da 353 Ronch et al. 2016), whereas Betula pendula and B. pubescens have greater tolerance to lower temperatures of the 354 coldest month, and B. pubescens has greater tolerance to higher annual precipitation (Beck et al. 2016). Thus, the dominance of Betula in conjunction with the absence of Larix points to contrasting early-Holocene moisture 356 conditions in the Maritime Alps compared with the central Alps. The importance of moisture conditions was also 
acknowledged when comparing past plant distributions from the currently moister northern Swiss Alps and the currently drier inner-alpine valleys (Lotter et al. 2006; Schwörer et al. 2014b) and may explain the early-

359 Holocene dominance of Betula in the Scandes Mountains despite the presence of Larix sibirica (Kullman and 360 Öberg 2015).

\section{Highest timberline position during the Holocene}

363 At Lac des Grenouilles, Betula dominated the treeline ecotone with scattered Pinus stands (probably P. mugo as suggested by the plant macrofossils) and Juniperus shrubs until ca. $8000 \mathrm{cal}$ BP, when Abies expanded. The timing of the Abies expansion is in good agreement with regional pollen data (de Beaulieu et al. 1994; Nakagawa 1998; Finsinger 2001). The dominance of temperate Abies at today's treeline elevation marks the highest timberline position, which was reached around 7500-7000 cal BP. While the stacked Alpine temperature reconstruction shows highest temperatures around $8500-8000$ cal BP, this interpretation is in good agreement with a chironomid-inferred temperature record from the Alps (Heiri et al. 2003) and from the northern the northern Apennines (Samartin et al. 2017) as well as with Global Circulation Models (Renssen et al. 2009), all showing $\sim 1.5^{\circ} \mathrm{C}$ higher-than-present temperatures during the Holocene Thermal Maximum (HTM) around 7500 cal BP. Some records also point to the establishment of progressively more oceanic conditions after $8000 \mathrm{cal}$ BP

373 (Magny et al. 2011). Although the local establishment of Abies was suggested by the marked rise of pollen percentages (Ponel et al. 2001), no Abies macrofossils were found in the nearby located Lac Long Inférieur at $2090 \mathrm{~m}$ asl (F. Damblon unpublished, see Finsinger 2001). This may suggest that Abies reached its upper limit at about 2000-2100 m asl during the HTM in the study area. However, compared to other Alpine records, $2100 \mathrm{~m}$ asl is a substantially lower mid-Holocene timberline elevation. Plant-macrofossil records document timberline c.

378 150-200 m above current timberline during the HTM to reach altitudes between c. 2300 and $2500 \mathrm{~m}$ asl (Tinner 379 and Theurillat 2003; Schwörer et al. 2014b). Thus, further plant-macrofossil records from sites at higher elevation may be needed to constrain the position reached by the upper limits of the timberline and the treeline in

381 the study area during the Holocene.

382 The occurrence of mid-Holocene plant-macrofossil assemblages with both A. alba and P. cembra is striking

383 because at present these two species thrive together in very few and isolated locations, mainly in the inner-alpine zone of the southwestern Alps. For instance, in the Valais (Switzerland) on steep and convex slopes around 1900-

$3852000 \mathrm{~m}$ asl (Lingg 1986), in the Susa Valley (Italy) at c. $1950 \mathrm{~m}$ asl (Dotta and Motta 2000) and in the 
388 (Mayer 1979). In these lower-subalpine stands, A. alba's abundance is generally low in comparison to other conifers, but there are clear signs of active regeneration (Lingg 1986; Dotta and Motta 2000) and even population expansion in response to land-use abandonment after the 1950s (Lingg 1983; Chauchard et al. 2010).

391 It has been suggested that inner-(western)alpine populations (ecotypes) maintained a stronger adaptive potential

392 to drought stress and strong irradiation, if compared to provenances from the moister southern, eastern and northern Alps (e.g. Marcet 1971, 1972; Mayer 1979; Kral 1989; Kral and Mayer 1993). However, there are still

394 critical knowledge gaps in this regard. For instance, while modern mtDNA maternal lineages and allozyme clusters of A. alba show little differences among Alpine populations (Liepelt et al. 2009), distinct interpopulational genetic variation (genetic distance, genetic differentiation) between stands within and outside the Alpine region as well as between neighbouring populations may point to processes of adaptation to different or specific environmental conditions (Hussendörfer 1999). It might be that the mtDNA and allozyme genomic regions identifying the haplotypes (Liepelt et al. 2009) bear little connection with adaptive genes for droughtstress response, which are starting to be uncovered (Behringer et al. 2015). Moreover, intraspecific variation in drought sensitivity of A. alba is yet not very well constrained (George et al. 2015).

402 By contrast, there is a substantially larger consensus on the view that these isolated inner-alpine P. cembra-A. alba (-L. decidua) mixed stands at very remote sites represent remnants of past and more widespread populations

404 (Lingg 1986; Kral and Mayer 1993; Tinner et al. 2013) whose occurrence is attested by mid-Holocene plantmacrofossil and stomata records (Welten 1982; Wick et al. 2003; Schwörer et al. 2014b; this study). Similarly, there is a large consensus indicating that $A$. alba populations declined due to increasing human pressure (fire disturbances, pasture, logging) at high-elevation sites (e.g. Markgraf 1969; Lingg 1986; Tinner et al. 2013),

408 suggesting marked contraction of the realized climatic niche of the species in response to prehistorical land use.

Relationships between vegetation dynamics and land-use phases

412 We found evidence of higher abundance of large herbivores and intensified land use activities (Figures 3 and 4)

413 during previously identified rock-art phases (Table 2; Huet 2017). The Neolithic Cardial phase (7450-7150 cal 414 BP) is attested by the finding of a ceramic artefact at Gias del Ciari as well as in other rock shelters (Conti 1940; 
415 Louis and Ségui 1949; Bianchi et al. 2011) in the study region. Based on this evidence, the first sign of human 416 occupation associated to agricultural activities in the area dates back to $7450-7150$ cal BP, thereby attesting that 417 the Vallée des Merveilles was one of the first Alpine areas being visited during the Neolithic (Binder 2005).

418 Indeed, trade and transhumance across this sector of the Alps may already have started between 7000 and 6000 419 cal BP (Ricq-de Bouard and Fedele 1993; Huet 2017). At Lac des Grenouilles, this phase is only characterised by 420 higher Urtica pollen and Sporormiella spores' abundance, when fire activity remained low. Instead, the Copper 421 Age phase (Chassean period (6200-5500 cal BP), and the Recent Bell-Beaker and Early Bronze Age phase (c. $4224250-3700 \mathrm{cal}$ BP)) are also associated with the presence of Cerealia and other cultural indicator pollen types, a 423 rise of total herb pollen, and increasing charcoal influx values. An increase of cultural pollen during the most 424 recent phase was also detected at Lac Long Inférieur (de Beaulieu 1977; see Table 1 in Huet 2017).

425 Although we found a good match between the new pollen record and the rock-art phases, our results indicate that the Chassean land-use phase lasted longer than suggested by Huet (2017). For instance, Urtica pollen abundance

427 actually increased at 5300 and remained high until 4900 cal BP, suggesting increasing nitrogen supply as e.g. 428 resulting from grazing activities. Similarly, charcoal influx and Poaceae pollen abundance did not decrease, and 429 overall arboreal pollen abundance did not increase until $4900 \mathrm{cal} \mathrm{BP}$, suggesting that land use with the use of fire 430 continued until the end of the Copper Age. Yet, the Copper Age land-use phase did not have persistent 431 consequences on ecosystems. For instance, although at the landscape-scale (as inferred from the pollen record) 432 Abies did not recover, local-scale Abies populations (as attested by plant-macrofossils) were able to re-establish 433 during the low fire-activity period and land-abandonment phase that occurred between 4900 and 4300 cal BP. 434 This transient recovery ended with the Bronze Age land-use phase (4250-3700 cal BP), when Abies and Betula 435 collapsed locally (macrofossils) and Betula and Pinus regionally (pollen). Interestingly, the timing of this land436 use phase matches with a major deforestation and land-use phase detected elsewhere in and around the Alps 437 (Gobet et al. 2003; Tinner et al. 2003; Finsinger and Tinner 2006). This suggests that Bronze Age land use was 438 pervasive at both low and high elevations in the Alps, possibly leading to irreversible changes such as the 439 disappearance of Abies alba treeline communities.

442 In the Alps, the development of larch meadows ("Lärchenwiesen"), a form of wood pastures with $L$. decidua 443 stands and dense grass-dominated herbaceous under-storey (Garbarino et al. 2011), is associated in several 
444 palaeoecological records to anthropogenic activities, in particular grazing after fire occurrence (Wagner et al. 4452015 and references therein). L. decidua is considered as a species being favoured for livestock herding, because 446 its light canopy permits the growth of suitable foraging ground cover (Motta and Lingua 2005). Moreover, with 447 its great bark thickness on mature individuals, a key fire-tolerance trait (Pellegrini et al. 2017), and the ability to 448 produce new foliage each year, L. decidua is rather fire resistant (Sullivan 1994) also because mature individuals 449 show relatively low mortality rates (Dupire et al. 2019). Conversely, due to its physiology and its ability to 450 colonize raw soils (Garbarino et al. 2010), L. decidua is less limited by soil moisture availability than other subalpine tree species (A. alba, P. abies, and P. cembra) (Schwörer et al. 2014a). However, although a decrease 452 in moisture availability might have been favourable for $L$. decidua at the expense of $A$. alba, there is no evidence 453 of a decrease in rainfall between 6000 and 4000 cal BP in lake-level records from the Alpine region (Figure 4), 454 which instead indicate higher precipitation between 4500 and the present when compared to mid-Holocene 455 (Magny et al. 2011, 2013). Based on this evidence and on the fact that $L$. decidua is the dominant tree species in 456 the Mont Bégo area today (Ozenda 1950; de Beaulieu 1977), it seems far more plausible to infer that the expansion of $L$. decidua at Lac des Grenouilles was triggered by excessive human fire disturance (see cross458 correlation analyses, Figure 5) while A. alba populations were strongly reduced. This interpretation regarding the causes of paramount vegetation changes is consistent with prior studies, which indicate that under low-

460 disturbance conditions $A$. alba can dominate forests under colder temperatures than observed today (Wick et al. 2003; Lotter et al. 2006; Tinner et al. 2013).

\section{Conclusions}

465 We present the first palaeoecological study that includes pollen, plant-macrofossil, and charcoal records from the 466 modern timberline (c. $2000 \mathrm{~m}$ asl) in the Mont Bégo area (Maritime Alps). The area is an iconic place for Alpine archaeology because it bears thousands rock-art engravings (Bicknell 1913; de Lumley 1995; Huet 2012) whose

468 age cannot be directly assessed. The new taxonomically highly-resolved palaeoecological record confirms most of the land-use phases (7450-7150, 6200-5500, and 4250-3700 cal BP) inferred based on rock-art typology (Huet

470 2017), and in addition unfolds local long-term timberline shifts and vegetation-composition changes in relation 471 to environmental changes (land-use, fire disturbances, and climatic changes). The absence of Larix macrofossils 472 suggests that early-Holocene conditions were moister than in dry inner-alpine valleys, where Larix played a 
473 more important role both in past as well as in modern timberline forests. After $8000 \mathrm{cal}$ BP, the timberline shifted

474 to higher elevation and mixed A. alba and P. cembra stands established around the study site above c. $2000 \mathrm{~m}$

475 a.s.1. during the Holocene Thermal Maximum (HTM), when the first rock-arts were probably engraved. At the

476 timberline, Abies populations were replaced during the Bronze Age (around $4000 \mathrm{cal}$ BP) by L. decidua

477 dominated subalpine forests, which are still dominant today in the study area (Ozenda 1950; de Beaulieu 1977).

478 Thus, A. alba populations were reduced at the colder-end of their natural distribution (Tinner et al. 2013), and

479 populations of $L$. decidua expanded in response to past land-use (with the use of fire) that allowed the

480 establishment of pasture woodlands. This implies that modern forested landscapes are markedly shaped by

481 prehistorical legacies, even in high-alpine remote areas (Willis and Birks 2006; Feurdean et al. 2009).

482

483

484

485

486 Acknowledgements

487 We are thankful to B. Ammann for her invaluable support, to W. Tanner, K. Finsinger and the guards of the Parc

488 National du Mercantour for help during fieldwork, to A.F. Lotter for introducing WF to the electro-osmotic

489 guillotine, to F. Oberli for processing a part of the pollen samples, and to the Parc National du Mercantour for

490 granting permission to collect sediments from the lake. We further thank the national program ARTEMIS for

491 funding some of the ${ }^{14} \mathrm{C}$ datings at the Saclay laboratory (LMC14), and the University of Bern and the École

492 Pratique des Hautes Études for financial support to WF and QV, respectively.

493

494

495

496 
499 Fig. 1 Maps showing (a) the location of Lac des Grenouilles in the Mont Bégo area (inset marks the location of

500 the Argentera Massif in Europe), and (b) the location of the study site (GREN) in relation to other sites discussed 501 in the text (BACH: Bachalpsee (Lotter et al. 2006); SÄG: Sägistalsee (Wick et al. 2003); IFF: Iffigsee (Schwörer 502 et al. 2014b); LdF: Lac de Fully (Finsinger and Tinner 2007); GR: Gouillé Rion (Tinner and Theurillat 2003; 503 Kaltenrieder et al. 2005a); CER: Lac de Cerin (Magny et al. 2011); LOUP: Lac du Loup (Blarquez et al. 2010); 504 LPA: Lago Piccolo di Avigliana (Finsinger and Tinner 2006); LLInf: Lac Long Inférieur (de Beaulieu 1977); 505 BAS: Lago Basso (Wick and Tinner 1997), and LSM: Lej da San Murezzan (Gobet et al. 2003)); ACC: Lago dell'Accesa (Magny et al. 2011)). Panel (c) shows the mapped geomorphological features around the lakes' catchment. The basemap in panel (b) shows the hygric continentality (Gams 1931, 1932; Ozenda 2002; Holtmeier 2009) recalculated using the WorldClim2 dataset (Fick and Hijmans 2017)

Fig. 2 Depth-age model for the Lac des Grenouilles cores plotted against depth below water surface. Grey horizontal bands indicate turbidites that were excluded from the depth-age model. Images of the two parallel and overlapping sediment cores are shown on the right

514 Fig. 3a Abundances of selected pollen and spores, and Sporormiella spores (as percentages of the terrestrial 515 pollen sum) from Lac des Grenouilles. Grey horizontal bands indicate land-use phases as inferred from

516 archaeological data (see Table 2). Continuous horizontal lines indicate statistically significant pollen-assemblage zones (LPAZ); the short-dashed line indicates the pollen-inferred Younger Dryas/Holocene boundary (see Table

518 1). Empty curves show $10 \times$ exaggerations

Fig. 3b Plant-macrofossil concentration record from Lac des Grenouilles. Grey horizontal bands indicate landuse phases as inferred from archaeological data (Table 2). Continuous horizontal lines indicate statistically significant pollen-assemblage zones (LPAZ); the short-dashed line indicates the pollen-inferred Younger Dryas/Holocene boundary (Table 1)

Fig. 4 Comparison of the main biotic and abiotic proxies for vegetation dynamics, fire, and climate. From top to bottom: Lake-level changes in the Jura Mountains (Lake Cerin) and in Central Italy (Lake Accesa) (digitized from Magny et al. 2011); mean December, January, February (DJF, blue line) and June, July, August (JJA, red line) insolation at $65^{\circ} \mathrm{N}$ (Laskar et al. 2004); stacked chironomid-inferred July-air temperatures for the Alpine region (Heiri et al. 2015); selected data from Lac des Grenouilles: pollen percentages (raw data: coloured areas (dark green: trees, light green: shrubs, yellow: herbs), interpolated and loess-fitted data (black lines) used for cross-correlation analyses (see Fig. 5), and plant-macrofossil concentrations (summed by genera; black bars; values 10×)); and charcoal-accumulation rate of charcoal counts (black bars; loess-fitted data: red lines). Vertical shaded areas (grey) indicate the land-use phases based on archaeology (Table 2)

Fig. 5 Cross-correlation of charcoal accumulation rates (CHARc) and pollen percentages (interpolated to 100- 
536 year intervals) showing trends of taxon responses to changes in fire activity up to lags $+/-4$, corresponding to 537 time periods of $+/-400$ years

538 
539 Table 1: Radiocarbon measurements of plant macrofossils used to establish the age-depth model $(*=$ rejected

$540{ }^{14} \mathrm{C}$ measurement; ${ }^{\uparrow}=$ master-core depth below water surface; ${ }^{\S}=$ corrected sediment depth that excludes

541 turbidites)

\begin{tabular}{|c|c|c|c|c|c|}
\hline Lab-ID & Material dated & $\begin{array}{l}\text { Age } \\
\left({ }^{14} \mathrm{C} \text { yrs BP }\right)\end{array}$ & $\begin{array}{l}\text { Age } \\
\text { (cal yrs BP) }\end{array}$ & Depth $(\mathrm{cm})^{\Phi}$ & Depth $(\mathrm{cm})^{\S}$ \\
\hline Surface & l & / & $-55 \pm 1$ & 286 & 0 \\
\hline Erl-4375 & Wood with bark & $3521 \pm 69$ & l & $587-586$ & $301-300$ \\
\hline Erl-4376 & Wood with bark & $3886 \pm 58$ & / & $602-601$ & $316-315$ \\
\hline Erl-4377 & Wood with bark & $4066 \pm 66$ & l & 609.5 & $323-322$ \\
\hline SacA-25565 & Plant macrofossils & $4100 \pm 35$ & / & 619-618 & $332-331$ \\
\hline Erl-4378 & Wood with bark & $4860 \pm 58$ & l & 638.7 & $351-350$ \\
\hline SacA-25566 & Plant macrofossils & $4725 \pm 40$ & / & $647-646$ & $355-354$ \\
\hline SacA-25567 & Plant macrofossils & $5810 \pm 45$ & / & $676-675$ & $380-379$ \\
\hline Erl-4379 & Wood with bark & $7708 \pm 76$ & / & $717-716$ & $417-416$ \\
\hline Erl-4380 & Wood with bark & $7600 \pm 68$ & l & $719-718$ & $419-418$ \\
\hline Erl-4381 & Wood with bark & $8119 \pm 69$ & / & $730-729$ & $430-429$ \\
\hline \multirow[t]{2}{*}{ Poz-7822 } & Plant macrofossils & $8990 \pm 50$ & / & $759-758$ & $459-458$ \\
\hline & Pollen-inferred age & / & $11500 \pm 250$ & $780-779$ & $477-476$ \\
\hline Poz-10812* & Plant macrofossils & $1725 \pm 35$ & / & 817 & 505 \\
\hline Poz-7907* & Plant macrofossils & $2135 \pm 35$ & & $821-819$ & $508-506$ \\
\hline
\end{tabular}


543 Table 2: Occupation phases determined based on archaeological findings in the Mont Bégo area (from Huet 544 2017)

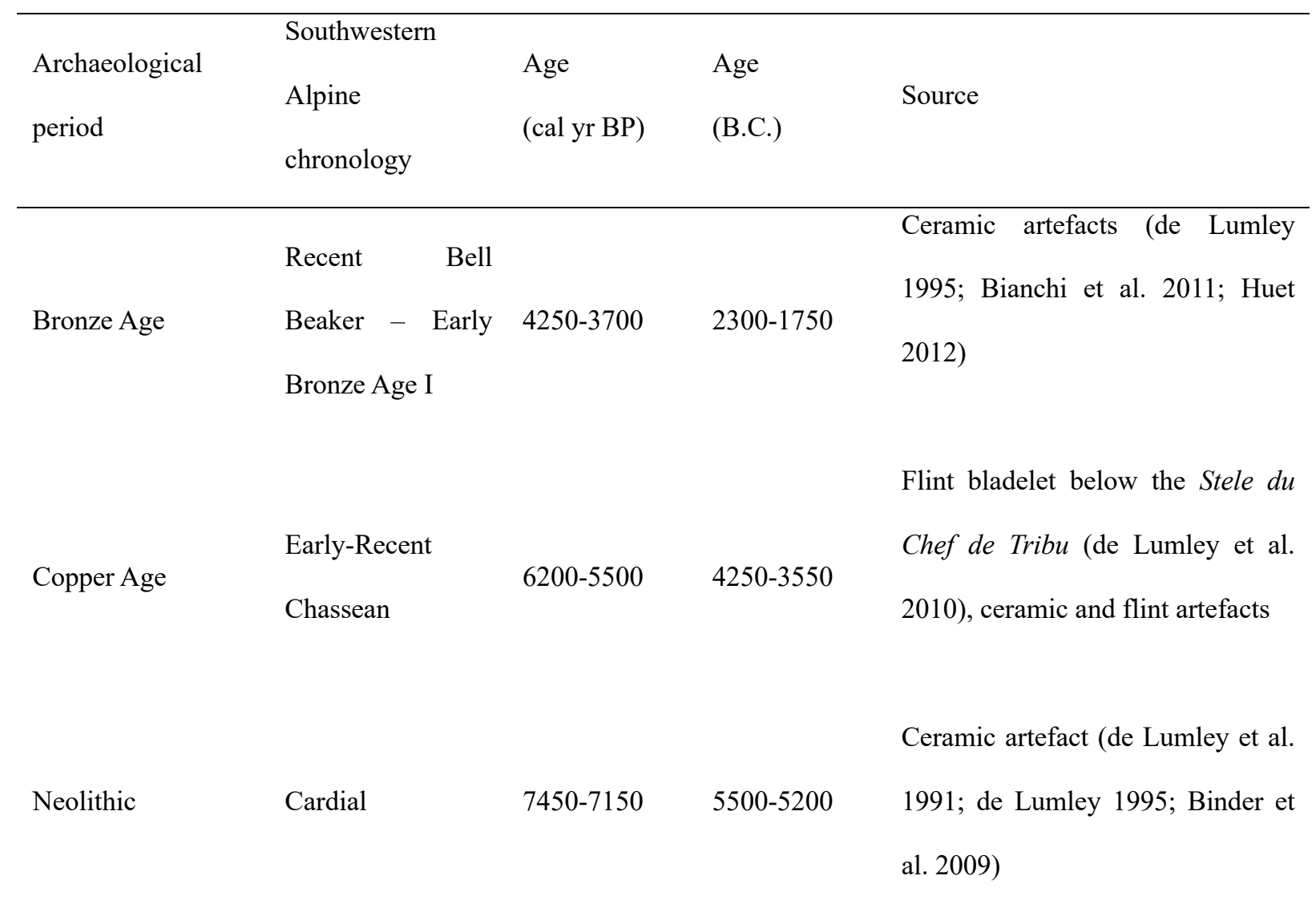




\section{References}

Adolf C, Wunderle S, Colombaroli D, et al (2018) The sedimentary and remote-sensing reflection of biomass burning in Europe. Glob Ecol Biogeogr 27:199-212. https://doi.org/10.1111/geb.12682

Ammann B, Knaap WO van der, Lang G, et al (2014) The potential of stomata analysis in conifers to estimate presence of conifer trees: examples from the Alps. Veg Hist Archaeobotany 23:249-264. https://doi.org/10.1007/s00334-014$0431-9$

Arcà A (2018) Honorato Lorenzo, Pietro Gioffredo e il Monbego, un manoscritto ritrovato. Prehist Alp 49:93-116

Arno SF, Hammerly RP (1984) Timberline: mountain and arctic forest frontiers. The Mountaineers, Seattle

Baker AG, Bhagwat SA, Willis KJ (2013) Do dung fungal spores make a good proxy for past distribution of large herbivores? Quat Sci Rev 62:21-31. https://doi.org/10.1016/j.quascirev.2012.11.018

Barbero M, Bono G (1970) Les sapinières des Alpes maritimes, de l'Authion à la Ligurie et de la Stura au Tanaro. Veröff Geobot Inst Eidg Tech Hochsch Stift Rübel Zür 140-168. https://doi.org/10.5169/SEALS-308331

Barbero M, Bono G, Mondino GP, Ozenda P (1973) Carte écologique des Alpes au 1/100 000: Feuilles de Nice-Menton et Viève-Cuneo. Doc Cartogr Ecol 12:

Beck P, Caudullo G, de Rigo D, Tinner W (2016) Betula pendula, Betula pubescens and other birches in Europe: distribution, habitat, usage and threats. In: San-Miguel-Ayanz J, Houston Durrant T, Mauri A, Caudullo G (eds) European Atlas of Forest Tree Species. Publ. Off. EU, Luxembourg, p e010226+

Behringer D, Zimmermann H, Ziegenhagen B, Liepelt S (2015) Differential Gene Expression Reveals Candidate Genes for Drought Stress Response in Abies alba (Pinaceae). PLOS ONE 10:e124564.

https://doi.org/10.1371/journal.pone.0124564

Bennett KD (1996) Determination of the number of zones in a biostratigraphical sequence. New Phytol 132:155-170

Bennett KD (2008) Psimpoll v. 4.26. http://chrono.qub.ac.uk/psimpoll/psimpoll.html. Accessed 11 Jul 2019

Berthel N, Schwörer C, Tinner W (2011) Impact of Holocene climate changes on alpine and treeline vegetation at Sanetsch Pass, Bernese Alps, Switzerland. Rev Palaeobot Palynol

Bianchi N, Huet T, Sandrone S (2011) Inventaire du matériel archéologique du gias du Ciari (Tende, Alpes-Maritimes, France).

Soprintendenza per i Beni Archeologici del Piemonte e del Museo Antichità Egizie - Museo Civico di Cuneo, Italy

Bicknell C (1913) A guide to the prehistoric rock engravings in the Italian Maritime Alps. Bessone, Bordighera

Binder D (2005) Les premiers agriculteurs et pasteurs en Provence au VIe millénaire. In: 15 ans d'archéologie en Provence-Alpes-Côte d'Azur. Edisud, pp 32-45

Binder D, Lepère C, Huet T (2009) Compte rendu de mission au Musée des Merveilles Tende. In: Matières premières, productions et usages du Paléolithique supérieur à l'âge du Bronze ancien, Projet Collectif de Recherche. pp $1-10$

Birks HH, Birks HJB (2000) Future uses of pollen analysis must include plant macrofossils. $\mathrm{J}$ Biogeogr 27:31-35

Birks HH, Bjune AE (2010) Can we detect a west Norwegian tree line from modern samples of plant remains and pollen? Results from the DOORMAT project. Veg Hist Archaeobotany 19:325-340. https://doi.org/10.1007/s00334-0100256-0

Birks HJB, Gordon AD (1985) Numerical Methods in Quaternary Pollen Analysis. Academic Press, London

Blaauw M (2010) Methods and code for 'classical' age-modelling of radiocarbon sequences. Quat Geochronol 5:512-518

Blarquez O, Carcaillet C, Bremond L, et al (2010) Trees in the subalpine belt since 11700 cal. BP: origin, expansion and alteration of the modern forest. The Holocene 20:139-146. doi: $10.1177 / 0959683609348857$

Brisset E, Guiter F, Miramont C, et al (2015) Lateglacial/Holocene environmental changes in the Mediterranean Alps inferred from lacustrine sediments. Quat Sci Rev 110:49-71.

https://doi.org/10.1016/j.quascirev.2014.12.004 
Chauchard S, Beilhe F, Denis N, Carcaillet C (2010) An increase in the upper tree-limit of silver fir (Abies alba Mill.) in the Alps since the mid-20th century: A land-use change phenomenon. For Ecol Manag in press. doi: 10.1016/j.foreco.2010.01.009

Cleveland WS, Devlin SJ (1988) Locally

Weighted Regression: An Approach to Regression Analysis by Local Fitting. J Am Stat Assoc 83:596-610

Conedera M, Tinner W, Crameri S, et al (2006) Taxon-related pollen source areas for lake basins in the southern Alps: an empirical approach. Veg Hist Archaeobotany 15:263-272. https://doi.org/10.1007/s00334-006-0056-8

Conedera M, Tinner W, Neff C, et al (2009) Reconstructing past fire regimes: methods, applications, and relevance to fire management and conservation. Quat Sci Rev 28:555-576. https://doi.org/10.1016/j.quascirev.2008.11.005

Conti C (1940) Scoperta della piu antica fase delle incisioni rupestri di monte Bego (Alpi Marittime). Boll Paletnologia Ital Nuova Ser $4: 2-30$

Conti C (1972) Corpus delle incisioni rupestri di Monte Bego. Istituto Internazionale di Studi Liguri, Bordighera

Cossart E (2008) Reconstitution de la géométrie d'un glacier disparu et modélisation des conséquences de sa disparition. Exemple du glacier durancien lors du Dernier Maximum Glaciaire. Rev Int Géomat 18:95-111. https://doi.org/10.3166/geo.18.95-111

Cossart E, Fort M, Bourlès D, et al (2012)

Deglaciation pattern during the

Lateglacial/Holocene transition in the southern

French Alps. Chronological data and geographical reconstruction from the Clarée Valley (upper Durance catchment, southeastern France). Palaeogeogr Palaeoclimatol Palaeoecol 315-316:109-123.

https://doi.org/10.1016/j.palaeo.2011.11.017

Da Ronch F, Caudullo G, Tinner W, de Rigo D (2016) Larix decidua and other larches in Europe: distribution, habitat, usage and threats. In: San-Miguel-Ayanz J, Houston Durrant T, Mauri A, Caudullo G (eds) European Atlas of Forest Tree Species. Publ. Off. EU, Luxembourg, p e01e492+

Davis OK (1987) Spores of the dung fungus $<\mathrm{i}>$ Sporormiella $<\mathrm{i} />$ : increased abundance in historic sediments and before Pleistocene megafaunal extinction. Quat Res 28:290-294

de Beaulieu JL (1977) Contribution pollenanalytique a l'histoire tardiglaciaire et holocène de la végétation des Alpes Meridionales Françaises. L'Univeristé d'Aix-Marseille III

de Beaulieu J-L, Richard H, Ruffaldi P, Clerc J (1994) History of vegetation, climate and human action in the French Alps and the Jura over the last 15,000 years. In: Festschrift Gerhard Lang. J. Cramer in der Gebr. Borntraeger

Verlagsbuchhandlung, Berlin-Stuttgart, pp 253275

de Lumley H (1995) Le grandiose et le sacré. Edisud, Aix-en-Provence

de Lumley H (1984) Les gravures rupestres de l'Age du Bronze de la Valleé des Merveilles, Mont Bego, Alpes Maritimes. Antropol Paris 88:613-647

de Lumley H, Echassoux A, Romain O, et al (2010) Une lame de faucille sous la stèle gravée Chalcolithique dite du «Chef de tribu», Vallée des Merveilles, région du Mont Bego, Tende, Alpes-Maritimes. L'Anthropologie 114:445-468. https://doi.org/10.1016/j.anthro.2010.07.005

de Lumley H, Mano L, Kadar S, et al (1991) Le Gias del Ciari à Tende, stratigraphie et attribution culturelle des niveaux archéologiques. Tendes Alpes-Maritimes, pp 146-152

Dotta A, Motta R (2000) Boschi di conifere montani. Indirizzi selvicolturali. Regione Piemonte, Blu Edizioni, Torino

Dupire S, Curt T, Bigot S, Fréjaville T (2019) Vulnerability of forest ecosystems to fire in the French Alps. Eur J For Res 138:813-830. https://doi.org/10.1007/s10342-019-01206-1

Elkington TT (1971) Dryas octopetala L. J Ecol 59:887-905

Faure-Muret A (1967) Saint-Martin-Vesubie-LeBoreon, Carte Géologique de la France 1/50 000, XXXVII-40-41. Bureau de Recherches Géologiques et Minières (BRGM), Orléans, France

Federici PR, Granger DE, Ribolini A, et al (2012) Last Glacial Maximum and the Gschnitz stadial in the Maritime Alps according to ${ }^{10} \mathrm{Be}$ cosmogenic dating. Boreas 41:277-291. https://doi.org/10.1111/j.15023885.2011.00233.x 
Federici PR, Ribolini A, Spagnolo M (2017) Glacial history of the Maritime Alps from the Last Glacial Maximum to the Little Ice Age. Geol Soc Lond Spec Publ 433:137-159. https://doi.org/10.1144/SP433.9

Feurdean AN, Willis KJ, Astaloş C (2009) Legacy of the past land-use changes and management on the 'natural' upland forest composition in the Apuseni Natural Park, Romania. The Holocene 19:967-981. https://doi.org/10.1177/0959683609337358

Fick SE, Hijmans RJ (2017) WorldClim 2: new $1-\mathrm{km}$ spatial resolution climate surfaces for global land areas. Int J Climatol 37:4302-4315. https://doi.org/10.1002/joc.5086

Finsinger W (2001) Vegetation history and human impact at the Lago del Vei del Bouc (Argentera Massif, Maritime Alps). Quaternaire $12: 223-233$

Finsinger W, Fevre J, Orbán I, et al (2018) Holocene fire-regime changes near the treeline in the Retezat Mts. (Southern Carpathians, Romania). Quat Int 477:94-105. https://doi.org/10.1016/j.quaint.2016.04.029

Finsinger W, Heiri O, Valsecchi V, et al (2007) Modern pollen assemblages as climate indicators in southern Europe. Glob Ecol Biogeogr 16:567582. doi:10.1111/j.1466-8238.2007.00313.x

Finsinger W, Kelly R, Fevre J, Magyari EK (2014) A guide to screening charcoal peaks in macrocharcoal-area records for fire-episodes reconstructions. The Holocene 24:1002-1008. https://doi.org/10.1177/0959683614534737

Finsinger W, Ribolini A (2001) Late Glacial to Holocene degalciation of the Colle del Vei del Bouc - Colle del Sabbione Area (Argentera Massif, Maritime Alps, Italy-France). Geogr Fis E Din Quat 24:141-156

Finsinger W, Schwörer C, Heiri O, et al (2019) Fire on ice and frozen trees? Inappropriate radiocarbon dating leads to unrealistic reconstructions. New Phytol 222:657-662. https://doi.org/10.1111/nph.15354

Finsinger W, Tinner W (2007) Pollen and plant macrofossils at Lac de Fully (2135 m asl): Holocene forest dynamics on a highland plateau in the Valais (Switzerland). The Holocene 17:1119-1127. doi: 10.1177/0959683607082552

Finsinger W, Tinner W (2006) Holocene vegetation and land-use changes in the forelands of the southwestern Alps, Italy. J Quat Sci 21:243-258

Finsinger W, Tinner W (2020) New insights on stomata analysis of European conifers 65 years after the pioneering study of Werner Trautmann (1953). Veg Hist Archaeobotany 29:393-406. https://doi.org/10.1007/s00334-019-00754-1

Gams H (1931) Die klimatische Begrenzung von Pflanzenarealen und die Verteilung der hygrischen Kontinentalität in den Alpen. Z Ges Für Erdkd Zu Berl 321-346

Gams H (1932) Die klimatische Begrenzung von Pflanzenarealen und die Verteilung der hygrischen Kontinentalität in den Alpen. II. Teil. Z Ges Für Erdkd Zu Berl 52-68, 178-198

Garbarino $M$, Lingua E, Martinez Subirà $M$, Motta R (2011) The larch wood pasture: structure and dynamics of a cultural landscape. Eur J For Res 130:491-502. https://doi.org/10.1007/s10342-010-0437-5

Garbarino M, Lingua E, Nagel TA, et al (2010) Patterns of larch establishment following deglaciation of Ventina glacier, central Italian Alps. For Ecol Manag 259:583-590. https://doi.org/10.1016/j.foreco.2009.11.016

Genries A, Finsinger W, Asnong H, et al (2012) Local versus regional processes: can soil characteristics overcome climate and fire regimes by modifying vegetation trajectories? J Quat Sci 27:745-756. https://doi.org/10.1002/jqs.2560

George J-P, Schueler S, Karanitsch-Ackerl S, et al (2015) Inter- and intra-specific variation in drought sensitivity in Abies spec. and its relation to wood density and growth traits. Agric For Meteorol 214-215:430-443. https://doi.org/10.1016/j.agrformet.2015.08.268

Giesecke T, Davis B, Brewer S, et al (2014) Towards mapping the late Quaternary vegetation change of Europe. Veg Hist Archaeobotany 23:75-86. https://doi.org/10.1007/s00334-0120390-y

Gill JL, McLauchlan KK, Skibbe AM, et al (2013) Linking abundances of the dung fungus Sporormiella to the density of bison: implications for assessing grazing by megaherbivores in palaeorecords. J Ecol 101:1125-1136. https://doi.org/10.1111/1365-2745.12130

Gil-Romera G, González-Sampériz P, LasherasÁlvarez L, et al (2014) Biomass-modulated fire dynamics during the Last Glacial-Interglacial 
Transition at the Central Pyrenees (Spain).

Palaeogeogr Palaeoclimatol Palaeoecol 402:113-

124. https://doi.org/10.1016/j.palaeo.2014.03.015

Gobet E, Tinner W, Bigler C, et al (2005) EarlyHolocene afforestation processes in the lower subalpine belt of the Central Swiss Alps as inferred from macrofossil and pollen records. The Holocene 15:672-686. https://doi.org/10.1191/0959683605hl843rp

Gobet E, Tinner W, Hochuli PA, et al (2003) Middle to Late Holocene vegetation history of the Upper Engadine (Swiss Alps): the role of man and fire. Veg Hist Archaeobotany 12:143163

Green DG (1981) Time Series and Postglacial Forest Ecology. Quat Res 15:265-277

Heiri C, Bugmann H, Tinner W, et al (2006) A model-based reconstruction of Holocene treeline dynamics in the Central Swiss Alps. J Ecol 94:206-216. doi: $10.1111 /$ j.13652745.2005.01072.x

Heiri O, Brooks SJ, Renssen H, et al (2014) Validation of climate model-inferred regional temperature change for late-glacial Europe. Nat Commun 5:4914.

https://doi.org/10.1038/ncomms5914

Heiri O, Ilyashuk B, Millet L, et al (2015) Stacking of discontinuous regional palaeoclimate records: Chironomid-based summer temperatures from the Alpine region. The Holocene 25:137149

Heiri O, Wick L, van Leeuwen JFN, et al (2003) Holocene tree immigration and the chironomid fauna of a small Swiss subalpine lake (Hinterburgsee, $1515 \mathrm{~m}$ asl). Palaeogeogr Palaeoclimatol Palaeoecol 189:35-53

Henne PD, Elkin CM, Reineking B, et al (2011) Did soil development limit spruce (Picea abies) expansion in the Central Alps during the Holocene? Testing a palaeobotanical hypothesis with a dynamic landscape model. J Biogeogr 38:933-949. https://doi.org/10.1111/j.13652699.2010.02460.x

Herring EM, Gavin DG, Dobrowski SZ, et al (2018) Ecological history of a long-lived conifer in a disjunct population. J Ecol 106:319-332. https://doi.org/10.1111/1365-2745.12826

Holtmeier F-K (2009) Mountain Timberlines: Ecology, Patchiness, and Dynamics. Springer Science \& Business Media
Holtmeier F-K, Broll G (2005) Sensitivity and response of northern hemisphere altitudinal and polar treelines to environmental change at landscape and local scales. Glob Ecol Biogeogr 14:395-410. https://doi.org/10.1111/j.1466822X.2005.00168.x

Huet $T$ (2017) New perspectives on the chronology and meaning of Mont Bégo rock art (Alpes-Maritimes, France). Camb Archaeol J 27:199-221.

https://doi.org/10.1017/S0959774316000524

Huet T (2012) Organisation spatiale et sériation des gravures piquetées du Mont Bégo. PhD, University Nice Sophia-Antipolis

Hussendörfer E (1999) Genetic variation of silver fir populations (Abies alba Mill.) in Switzerland. For Genet 6:101-113

Kaltenrieder P, Tinner W, Ammann B (2005a) Long-term vegetation history at timberline in the Swiss Alps (Alpe d'Essertse, VS). Bot Helvetica 115:137-154

Kaltenrieder P, Tinner W, Ammann B (2005b) Zur Langzeitökologie des Lärchen-Arvengürtels in den südlichen Walliser Alpen. Bot Helvetica 115:137-154. https://doi.org/10.1007/s00035005-0722-y

Kharbouch M (2000) L'homme et la végétation dans la région du mont Bego (Tende, AlpesMaritimes) depuis des millénaires. Comptes Rendus Académie Sci - Ser IIA - Earth Planet Sci 330:889-894. https://doi.org/10.1016/S12518050(00)00219-6

Körner C (2003) Alpine Plant Life - Functional Plant Ecology of High Mountain Ecosystems. Springer Verlag, Berlin Heidelberg

Körner C, Paulsen J (2004) A world-wide study of high altitude treeline temperatures. J Biogeogr 31:713-732

Kral F (1989) Le vicende del popolamento forestale sulle Alpi italiane. L'Italia For E Mont 44:107-131

Kral F, Mayer H (1993) Postglaziale Entstehung und Aufbau tannenreicher Wälder Europas. Festschr Zoller Diss Bot 196:305-316

Kullman L, Öberg L (2015) New Aspects of High-Mountain Palaeobiogeography: A Synthesis of Data from Forefields of Receding Glaciers and Ice Patches in the Tärna and Kebnekaise Mountains, Swedish Lapland. ARCTIC 68:141. https://doi.org/10.14430/arctic4480 
Landolt E (2003) Unsere Alpenflora. Gustav Fisher, Stuttgart

Lang G, Tobolski K (1985) Hobschensee - LateGlacial and Holocene environment of a lake near the timberline. In: Swiss Lake and Mire Environments during the last 15,000 years. Dissertationes Botanicae. J. Cramer, Vaduz, pp 209-228

Larocque I, Finsinger W (2008) Late-glacial chironomid-based temperature reconstructions for Lago Piccolo di Avigliana in the southwestern Alps (Italy). Palaeogeogr Palaeoclimatol Palaeoecol 257:207-223. doi:10.1016/j.palaeo.2007.10.021

Laskar J, Robutel P, Joutel F, et al (2004) A longterm numerical solution for the insolation quantities of the Earth. Astron Astrophys 428:261-285. https://doi.org/10.1051/00046361:20041335

Leys B, Finsinger W, Carcaillet C (2014) Historical range of fire frequency is not the Achilles' heel of the Corsican black pine ecosystem. J Ecol 102:381-395. https://doi.org/10.1111/1365-2745.12207

Liepelt S, Cheddadi R, de Beaulieu J-L, et al (2009) Postglacial range expansion and its genetic imprints in Abies alba (Mill.) - A synthesis from palaeobotanic and genetic data. Rev Palaeobot Palynol 153:139-149. https://doi.org/10.1016/j.revpalbo.2008.07.007

Lingg WA (1986) Ökologie der inneralpinen Weisstannenvorkommen (Abies alba Mill.) im Wallis (CH). Mitteilungen Eidgenöss Anst Für Forstl Vers 62:331-464

Lingg WA (1983) Waldbauliche Bedeutung und Geographische Verbreitung der Weisstanne im Wallis ausserhabl des Buchenareals. Bull Murithienne 100:117-128

Lotter AF, Birks HJB, Eicher U, et al (2000) Younger Dryas and Allerød summer temperatures at Gerzensee (Switzerland) inferred from fossil pollen and cladoceran assemblages. Palaeogeogr Palaeoclimatol Palaeoecol 159:349-361

Lotter AF, Heiri O, Hofmann W, et al (2006) Holocene timberline dynamics at Bachalpsee, a lake at $2265 \mathrm{~m}$ a.s.1. in the northern Swiss Alps. Veg Hist Archaeobotany 15:295-307

Louis M, Ségui J (1949) Le Gias del Ciari (Mont Bego) (Commune de Tende, Alpes-Maritimes). Gallia 7:141-159. https://doi.org/10.3406/galia.1949.2131

Machu P, Mano L, Plisson H, Bressy C (2007) Provenance et utilisation du silex dans les AlpesMaritimes, l'exemple de la région du Mont Bégo. In: Daudray D (ed) Actes du XIe colloque sur les Alpes dans l'Antiquité, Champsec/Val de Bagnes/Valais-Suisse. Bulletin d'études préhistoriques et archéologiques alpines, Aosta, pp 432-437

Magny M, Bossuet G, Ruffaldi P, et al (2011) Orbital imprint on Holocene palaeohydrological variations in west central Europe as reflected by lake level changes at Cerin (Jura Mountains, eastern France). J Quat Sci 26:171-177. doi: $10.1002 /$ jqs. 1436

Magny M, Combourieu-Nebout N, de Beaulieu JL, et al (2013) North-south palaeohydrological contrasts in the central Mediterranean during the Holocene: tentative synthesis and working hypotheses. Clim Past 9:2043-2071. https://doi.org/10.5194/cp-9-2043-2013

Malaroda R, Carraro F, Dal Piaz GV, et al (1970) Carta geologica del Massiccio dell'Argentera alla scala 1:50.000 e Note illustrative. Mem Della Soc Geol Ital 9:557-663

Malowerschnig B, Sass O (2014) Long-term vegetation development on a wildfire slope in Innerzwain (Styria, Austria). J For Res 25:103111. https://doi.org/10.1007/s11676-014-0435-4

Marcet E (1971) Versuche zur Dürreresistenz inneralpiner "Trockentannen" (Abies alba Mill.). Schweiz Z Für Forstwes 122:117-134

Marcet E (1972) Versuche zur Dürreresistenz inneralpiner "Trockentannen" (Abies alba Mill.) 2. Mitteilung. Schweiz Z Für Forstwes 123:763766

Markgraf V (1969) Moorkundliche und vegetationsgeschichtliche Untersuchungen an einem Moorsee and der Waldgrenze im Wallis. Bot Jahrb 89:1-63

Marlon J, Bartlein PJ, Carcaillet C, et al (2008) Climate and human influences on global biomass burning over the past two millennia. Nat Geosci 1:697-702

Mayer H (1979) Il ruolo selvicolturale dell'abete sulle Alpi e Prealpi centro-orientali. Ann Accad Ital Sci For 28:245-265

Merkt J, Streif H (1970) Stechrohr-Bohrgeräte für limnische und marine Lockersedimente. Geol Jahrb 88:137-148 
Millennium Ecosystem Assessment (2005)

Ecosystems and Human Well-being: Synthesis. Island Press, Washington, DC

Moore PD, Webb JA, Collinson ME (1998)

Pollen analysis. Blackwell Science Ltd, Oxford

Motta R, Lingua E (2005) Human impact on size, age, and spatial structure in a mixed European larch and Swiss stone pine forest in the Western Italian Alps. Can J For Res 35:18091820. https://doi.org/10.1139/x05-107

Nakagawa T (1998) Etudes palynologiques dans les Alpes Francaises centrales et meridionales: Histoire de la végétation Tardiglaciaire et Holocene. Université de Marseille III

Orbán I, Birks HH, Vincze I, et al (2018) Treeline and timberline dynamics on the northern and southern slopes of the Retezat Mountains (Romania) during the late glacial and the Holocene. Quat Int 477:59-78. https://doi.org/10.1016/j.quaint.2017.03.012

Oris F, Ali AA, Asselin H, et al (2014) Charcoal dispersion and deposition in boreal lakes from 3 years of monitoring: Differences between local and regional fires. Geophys Res Lett 41:67436752. https://doi.org/10.1002/2014GL060984

Ortu E, David F, Caramiello R (2003) Man's role in the vegetation history in the Ellero Valley (Maritime Alps, Italy). C R Biol 326:631-637

Ozenda P (1985) La végétation de la chaine alpine. Masson, Paris

Ozenda $\mathrm{P}$ (1950) Caractères généraux des AlpesMaritimes (Relief, sol, climat, végétation). Bull Société Bot Fr 97:7-17. https://doi.org/10.1080/00378941.1950.1083483 8

Ozenda P (2002) Perspectives pour une Geobiologie des Montagnes. Presses polytechniques et universitaires romandes, Lausanne, Switzerland

Pellegrini AFA, Anderegg WRL, Paine CET, et al (2017) Convergence of bark investment according to fire and climate structures ecosystem vulnerability to future change. Ecol Lett. https://doi.org/10.1111/ele.12725

Ponel P, Andrieu-Ponel V, Parchoux F, et al (2001) Late-glacial and Holocene high-altitude environmental changes in Vallée des Merveilles (Alpes-Maritimes, France): insect evidence. J Quat Sci 16:795-812.

https://doi.org/10.1002/jqs.634
Punt W, Blackmore S, Clarke GCS (1976)

Northwest European Pollen Flora: vol 1 (1976); vol 2 (1980); vol 3 (1981); vol 4 (1984); vol 5 (1988); vol 6 (1991); vol 7 (1996). Elsevier, Amsterdam

R Core Team (2017) R: A language and environment for statistical computing. $\mathrm{R}$ Foundation for Statistical Computing, Vienna, Austria

Rasmussen SO, Bigler M, Blockley SP, et al (2014) A stratigraphic framework for abrupt climatic changes during the Last Glacial period based on three synchronized Greenland ice-core records: refining and extending the INTIMATE event stratigraphy. Quat Sci Rev 106:14-28. https://doi.org/10.1016/j.quascirev.2014.09.007

Reille M (1992) Pollen et spores d'Europe et d'Afrique du nord. Laboratoire de Botanique Historique et Palynologie, Marseille

Reimer PJ, Bard E, Bayliss A, et al (2013) IntCal13 and Marine13 Radiocarbon Age Calibration Curves 0-50,000 Years cal BP. Radiocarbon 55:1869-1887.

https://doi.org/10.2458/azu_js_rc.55.16947

Renssen H, Seppä H, Heiri O, et al (2009) The spatial and temporal complexity of the Holocene thermal maximum. Nat Geosci 2:410-413

Rey F, Gobet E, Schwörer C, et al (2019) Causes and mechanisms of synchronous succession trajectories in primeval Central European mixed Fagus sylvatica forests. J Ecol 107:1392-1408. https://doi.org/10.1111/1365-2745.13121

Rey F, Schwörer C, Gobet E, et al (2013) Climatic and human impacts on mountain vegetation at Lauenensee (Bernese Alps, Switzerland) during the last 14,000 years. The Holocene 23:1415-1427. https://doi.org/10.1177/0959683613489585

Ribolini A, Chelli A, Guglielmin M, Pappalardo M (2007) Relationships between glacier and rock glacier in the Maritime Alps, Schiantala Valley, Italy. Quat Res 68:353-363.

https://doi.org/10.1016/j.yqres.2007.08.004

Ribolini A, Fabre D (2006) Permafrost existence in rock glaciers of the Argentera Massif, Maritime Alps, Italy. Permafr Periglac Process 17:49-63. https://doi.org/10.1002/ppp.548

Ribolini A, Guglielmin M, Fabre D, et al (2010) The internal structure of rock glaciers and recently deglaciated slopes as revealed by 
geoelectrical tomography: insights on permafrost and recent glacial evolution in the Central and Western Alps (Italy-France). Quat Sci Rev 29:507-521.

https://doi.org/10.1016/j.quascirev.2009.10.008

Ricq-de Bouard M, Fedele FG (1993) Neolithic

Rock Resources across the Western Alps:

Circulation Data and Models. Geoarchaeology Int J 8:1-22

Samartin S, Heiri O, Joos F, et al (2017) Warm Mediterranean mid-Holocene summers inferred from fossil midge assemblages. Nat Geosci. https://doi.org/10.1038/ngeo2891

Samartin S, Heiri O, Vescovi E, et al (2012)

Lateglacial and early Holocene summer temperatures in the southern Swiss Alps reconstructed using fossil chironomids. J Quat Sci 27:279-289. https://doi.org/10.1002/jqs. 1542

Schöneberger W, Wasem U (1997)

Wiederbewaldung einer Waldbrandfläche in der subalpinen Stufe bei Müstair. Schweiz Z Für Forstwes 148:405-424

Schwander J, Eicher U, Ammann B (2000) Oxygen isotopes of lake marl at Gerzensee and Leysin (Switzerland), covering the Younger Dryas and two minor oscillations, and their correlation to the GRIP ice core. Palaeogeogr Palaeoclimatol Palaeoecol 159:203-214

Schwörer C, Colombaroli D, Kaltenrieder P, et al (2015) Early human impact (5000-3000 BC) affects mountain forest dynamics in the Alps. $\mathrm{J}$ Ecol 103:281-295. https://doi.org/10.1111/13652745.12354

Schwörer C, Henne PD, Tinner W (2014a) A model-data comparison of Holocene timberline changes in the Swiss Alps reveals past and future drivers of mountain forest dynamics. Glob Change Biol 20:1512-1526.

https://doi.org/10.1111/gcb.12456

Schwörer C, Kaltenrieder P, Glur L, et al (2014b) Holocene climate, fire and vegetation dynamics at the treeline in the Northwestern Swiss Alps. Veg Hist Archaeobotany 23:479-496. https://doi.org/10.1007/s00334-013-0411-5

Sjögren P, van der Knaap WO, Huusko A, van Leeuwen JFN (2008) Pollen productivity, dispersal, and correction factors for major tree taxa in the Swiss Alps based on pollen-trap results. Rev Palaeobot Palynol 152:200-210. https://doi.org/10.1016/j.revpalbo.2008.05.003
Spagnolo M, Ribolini A (2019) Glacier extent and climate in the Maritime Alps during the Younger Dryas. Palaeogeogr Palaeoclimatol Palaeoecol 536:109400. https://doi.org/10.1016/j.palaeo.2019.109400

Stähli M, Finsinger W, Tinner W, Allgöwer B (2006) Wildland fire history and fire ecology of the Swiss National Park (Central Alps): New evidence from charcoal, pollen and plant macrofossils. The Holocene 16:805-817.

Sturm M, Matter A (1972) The Electro-Osmotic Guillotine, a New Device for Core Cutting. J Sediment Res 42:

Sugita S (1994) Pollen representation of vegetation in Quaternary sediments - theory and method in patchy vegetation. J Ecol 82:881-897

Sullivan J (1994) Larix decidua. In: Fire Effects Information System. U.S. Department of Agriculture, Forest Service, Rocky Mountain Research Station, Fire Sciences Laboratory, $p$ Available:

https://www.fs.fed.us/database/feis/plants/tree/lar dec/all.html [2019, December 6]

Tinner W (2007) Treeline studies. In: Elias SA (ed) Encyclopedia of Quaternary Science. Elsevier B.V., Amsterdam, The Netherlands, pp 2374-2384

Tinner W, Ammann B, Germann P (1996) Treeline fluctuations recorded for 12,500 years by soil profiles, pollen, and plant macrofossils in the Central Swiss Alps. Arct Alp Res 28:131-147

Tinner W, Colombaroli D, Heiri O, et al (2013) The past ecology of Abies alba provides new perspectives on future responses of silver fir forests to global warming. Ecol Monogr 83:419439. https://doi.org/10.1890/12-2231.1

Tinner W, Conedera M, Gobet E, et al (2000) A palaeoecological attempt to classify fire sensitivity of trees in the southern Alps. The Holocene 10:565-574

Tinner W, Hu FS (2003) Size parameters, sizeclass distribution and area-number relationship of microscopic charcoal: relevance for fire reconstruction. The Holocene 13:499-505

Tinner W, Hubschmid P, Wehrli M, et al (1999) Long-term forest fire ecology and dynamics in southern Switzerland. J Ecol 87:273-289

Tinner W, Kaltenrieder P (2005) Rapid responses of high-mountain vegetation to early Holocene environmental changes in the Swiss Alps. J Ecol 


\section{3:936-947}

Tinner W, Lotter AF, Ammann B, et al (2003) Climatic change and contemporaneous land-use phases north and south of the Alps $2300 \mathrm{BC}$ to 800 AD. Quat Sci Rev 22:1447-1460

Tinner W, Theurillat J-P (2003) Uppermost limit, extent, and fluctuations of the timberline and treeline ecotone in the Swiss Central Alps during the past 11,500 years. Arct Antarct Alp Res $35: 158-169$

Tinner W, Vescovi E (2005) Treeline ecology and oscillations in the Alps from the Pleniglacial to the present. Studi Trentini Sci Nat Acta Geol $82: 7-15$

Trautmann W (1953) Zur Unterscheidung fossiler Spaltöffnungen der mitteleuropäischen Coniferen. Flora 140:523-533.

https://doi.org/10.1016/S0367-1615(17)31952-3

Venables WN, Ripley BD (2002) Modern Applied Statistics with S, 4th edn. SpringerVerlag, New York

von Grafenstein U, Eicher U, Erlenkeuser H, et al (2000) Isotope signature of the Younger Dryas and two minor oscillations at Gerzensee (Switzerland): palaeoclimatic and palaeolimnologic interpretation based on bulk and biogenic carbonates. Palaeogeogr Palaeoclimatol Palaeoecol 159:215-229

Wagner S, Litt T, Sánchez-Goñi M-F, Petit RJ (2015) History of Larix decidua Mill. (European larch) since $130 \mathrm{ka}$. Quat Sci Rev 124:224-247. https://doi.org/10.1016/j.quascirev.2015.07.002

Walther G, Beißner S, Burga CA (2005) Trends in the upward shift of alpine plants. J Veg Sci 16:541-548. https://doi.org/10.1111/j.16541103.2005.tb02394.x

Welten M (1982) Vegetationsgeschichtliche Untersuchungen in den westlichen Schweizer Alpen: Bern-Wallis. Denkschr Schweiz Naturforschenden Ges 95:1-104

Whitlock C, Larsen C (2001) Charcoal as a fire proxy. In: Smol JP, Birks HJB, Last WM, Last WM (eds) Terrestrial, Algal, and Siliceous Indicators. Kluwer Academic Publishers, Dordrecht, The Netherlands, pp 75-97

Wick L, Tinner W (1997) Vegetation Changes and Timberline Fluctuations in the Central Alps as Indicators of Holocene Climatic Oscillations. Arct Alp Res 29:445.

https://doi.org/10.2307/1551992
Wick L, van Leeuwen JFN, van der Knaap WO, Lotter AF (2003) Holocene vegetation development in the catchment of Sägistalsee ( $1935 \mathrm{~m}$ asl), a small lake in the Swiss Alps. J Paleolimnol 30:261-272. https://doi.org/10.1023/A:1026088914129

Willis KJ, Birks HJB (2006) What is natural? The need for a long-term perspective in biodiversity conservation. Science 314:12611265 